\title{
PELATIHAN MENYUSUN RENCANA PELAKSANAAN PEMBELAJARAN HARIAN DALAM MENINGKATKAN KINERJA GURU NONFORMAL DI KORWIL BIDANG PENDIDIKAN KECAMATAN KOKOP KABUPATEN BANGKALAN
}

\author{
Sayadi \\ Penilik PAUD Korwil Bidang Pendidikan Kecamatan Kokop Kabupaten Bangkalan \\ Email : achsayadi2@gmail.com
}

\begin{abstract}
Abstrak
Rencana Pelaksanaan Pembelajaran Harian menggambarkan prosedur dan pengorganisasian kegiatan pembelajaran yang akan dilakukan untuk mencapai suatu kompetensi dasar yang telah ditetapkan dalam standar isi dan dijabarkan dalam Rencana Kegiatan Harian. Peneltian ini merupakan Penelitian Tindakan Sekolah yang bertujuan untuk meningkatkan kinerja guru dalam menyusun Rencana Pelaksanaan Pembelajaran Harian. Hasil penelitian ini menunjukkan bahwa dalam pelaksanaan prasiklus para peserta hanya mampu mendapat nilai rata-rata 64 hingga 72 setiap individu, ini artinya di kecamatan Kokop, para peserta belum mampu menyusun Rencana Pelaksanaan Pembelajaran Harian dengan baik. Sedangkan pada siklus I ditemukan bahwa kinerja guru mulai meningkat, hal ini dapat dilihat dari hasil pelaksanaan siklus I ini peserta mampu mendapat nilai rata-rata 70 hingga 80 setiap individu, artinya mereka belum mampu membuat Rencana Pelaksanaan Pembelajaran Harian dengan baik serta belum memenuhi kriteria yang diharapkan, oleh karena itu pelatihan dilanjut pada siklus berikutnya. Berdasarkan hasil pelaksanaan siklus II ini para peserta mampu mendapat nilai rata-rata 80 hingga 90 setiap individu, Dari hasil siklus II tersebut telah tercapai tujuan pelaksanaan pelatihan, oleh karena itu siklus dihentikan.
\end{abstract}

Kata Kunci : Peningkatan kinerja guru, penyusunan RPPH, kemampuan guru.

\begin{abstract}
The Daily Learning Implementation Plan describes the procedures and organization of learning activities that will be carried out to achieve a basic competency that has been defined in the content standards and described in the Daily Activity Plan. This research is a School Action Research which aims to improve teacher performance in preparing the Daily Learning Implementation Plan. The results of this study indicate that in the pre-cycle implementation, the participants were only able to get an average score of 64 to 72 for each individual, this means that in the Kokop sub-district, the participants have not been able to prepare the Daily Learning Implementation Plan properly. While in the first cycle it was found that the teacher's performance began to increase, this can be seen from the results of the implementation of the first cycle, the participants were able to get an average score of 70 to 80 for each individual, meaning that they had not been able to make the Daily Learning Implementation Plan well and did not meet the criteria set out in the first cycle. expected, therefore the training was continued in the next cycle. Based on the results of the implementation of the second cycle, the participants were able to get an average score of 80 to 90 for each individual. From the results of the second cycle, the objectives of the training were achieved, therefore the cycle was stopped.
\end{abstract}

Keywords : Improving teacher performance, preparing Daily Learning Implementation Plans, teacher abilities 


\section{PENDAHULUAN}

Membangun pendidikan merupakan suatu upaya untuk mencerdaskan kehidupan dan meningkatkan kualitas bangsa Indonesia. Pendidikan diharapkan mampu membentuk manusia menjadi beriman dan bertaqwa kepada Tuhan Yang Maha Esa, berakhlak mulia, sehat, berilmu, mandiri, demokratis, dan bertanggungjawab sehingga bangsa Indonesia menjadi berkarakter kemudian terwujud masyarakat yang adil dan makmur berdasarkan Pancasila dan UUD 1945. Pendidikan adalah proses pembentukan diri secara utuh, dalam arti pengembangan segenap potensi dalam pemenuhan semua komitmen manusia. Adapun mengembangkan potensi diri manusia dapat diberikan pendidikan sejak kecil melalui Pendidikan Anak Usia Dini (PAUD).

Pendidikan Anak Usia Dini (PAUD) diberikan kepada anak dengan usia 0-8 tahun, baik melalui jalur formal, non formal, ataupun informal. Karena pada usia tersebut merupakan usia emas sehingga perkembangan anak dapat diarahkan dengan baik. Sedangkan menurut UU No. 20 Tahun 2003 tentang Sistem Pendidikan Nasional pada Bab 1, Pasal 1, ayat 14, Pendidikan Anak Usia Dini merupakan upaya pembinaan yang ditujukan kepada anak sejak lahir sampai dengan usia 6 tahun yang dilakukan melalui pemberian rangsangan pendidikan untuk membantu pertumbuhan dan perkembangan jasmani serta rohani. Setiap lembaga pendidikan tentunya memerlukan sebuah pengelolaan yang baik, salah satunya adalah Pendidikan Anak Usia Dini (PAUD) yang tidak terlepas dari standar nasional pendidikan dalam proses pengelolaannya.

Para ahli mengatakan bahwa anak usia dini adalah anak yang dilahirkan sampai usia 0-6 tahun. Usia ini merupakan usia yang sangat menentukan dalam pembentukan karakter dan kepribadian anak. Pada usia dini merupakan periode awal yang paling penting dan mendasar sepanjang rentang pertumbuhan serta mengembangkan kehidupan manusia. ${ }^{1} \mathrm{Hal}$ ini adalah masa emas atau yang biasa disebut masa golden age dimana kemampuan otak anak dalam berpikir berkembang pesat hingga mencapai $80 \%$ karena fisik dan motorik anak berkembang dan bertumbuh dengan cepat dan baik emosional, intelektual, maupun moral (budi pakerti). ${ }^{2}$ Hal tersebut menjadi dasar utama mengapa pentingnya pendidikan untuk anak usia dini sebagaimana pada tahap-tahap perkembangan anak. Juga ada pendapat lain menyebutkan bahwa anak usia dini ialah kelompok anak yang berada dalam proses pertumbuhan dan perkembangan yang bersifat. Yaitu, pola pertumbuhan dan perkembangan (koordinasi motorik halus dan kasar), inteligensi (daya pikir, daya cipta, kecerdasan emosi, dan kecerdasan spiritual), sosial emosional (sikap dan perilaku serta agama), bahasa, dan komunikasi yang khusus sesuai dengan tingkat pertumbuhan dan perkembangan anak. Jadi dapat dipahami bahwa anak usia dini adalah berkisar usia 0-6 tahun yang memiliki pertumbuhan dan perkembangan yang luar biasa sehingga memunculkan berbagai keunikan pada dirinya. Pada tahap inilah, masa yang tepat untuk menanamkan nilai-nilai kebaikan yang nantinya diharapkan dapat membentuk kepribadian. ${ }^{3}$

Standar proses adalah terdiri dari perencanaan pembelajaran, pelaksanaan pembelajaran, penilaian hasil pembelajaran, dan pengawasan pembelajaran. Sedangkan

\footnotetext{
${ }^{1}$ Novan Andri Wiyani and Barnawi, Format PAUD (Yogyakarta: Ar Ruzz Media, 2012).

${ }^{2}$ Mursid, Pengembangan Pembelajaran PAUD (Bandung: Remaja Rosdakarya, 2016).

${ }^{3}$ Muhammad Fadillah, Desain Pembelajaran PAUD (Yogyakarta: Ar Ruzz Media, 2012).
} 
yang menjadi persyaratan pelaksanaan pembelajaran adalah Silabus dan Rencana Pelaksanaan Pembelajaran Harian (RPPH). Adapun pelaksanaan pembelajaran adalah tatap muka, tutorial, dan mandiri. Penilaian hasil pembelajaran adalah standar penilaian pendidikan dan panduan penilaian kelompok mata pelajaran. Sedangkan pengawasan pembelajaran adalah pemantauan, supervisi, evaluasi, dan pelaporan.

Rencana Pelaksanaan Pembelajaran Harian disusun untuk setiap KD yang dapat dilaksanakan dalam aktivitas pembelajaran. Pendidik merancang penggalan RPPH untuk setiap aktivitas pembelajaran yang disesuaikan dengan penjadwalan di satuan pendidikan. Prinsip-prinsip penyusunannya adalah memperhatikan perbedaan individu peserta didik, mendorong partisipasi aktif peserta didik, mengembangkan budaya membaca dan menulis, memberikan umpan balik dan tindak lanjut, keterkaitan dan keterpaduan, menerapkan teknologi informasi dan komunikasi. Adapun komponen RPPH adalah berkisar pada identitas mata pelajaran, standar kompetensi, kompetensi dasar, indikator pencapaian kompetensi, tujuan pembelajaran, materi ajar, alokasi waktu, metode pembelajaran, kegiatan pembelajaran, penilaian hasil belajar, dan sumber belajar.

Guru mempunyai peran dan kedudukan yang sangat strategis dalam pembangunan nasional khususnya dalam bidang pendidikan. Guru didefinisikan sebagai pendidik profesional dengan tugas utama mendidik, mengajar, membimbing, mengarahkan, melatih, menilai dan mengevaluasi peserta didik. Dengan ditegaskannya sebagai pekerjaan professional, otomotis menuntut adanya prinsip profesionalitas yang selayaknya dijungjung tinggi dan dipraktekkan oleh para guru, seorang guru hendaknya memiliki kualifikasi, kompetensi dan sertifikasi yang jelas.

Mendidik berarti mengembangkan nilai-nilai hidup yang berkarakter. Mengajar berarti mengembangkan ilmu pengetahuan dan teknologi. Sedangkan melatih berarti mengembangkan keterampilan individu peserta didik. Disamping itu, tugas guru di sekolah adalah harus menjadi orang tua kedua dari peserta didik. Guru juga harus menarik perhatian sehingga menjadi idola peserta didik. Pelajaran yang diberikan pun hendaknya dapat menjadi motivasi bagi peserta didik untuk berpacu dalam belajar. Oleh sebab itu kinerja seorang guru sangat penting, karena objek yang menjadi sasaran adalah mengajar peserta didik, kwalitas yang dididik tergantung pada yang mendidik, jika seorang guru bisa menempatkan diri sebagai pendidik yang memiliki kapasitas dan kinerja, maka dalam mengarahkan anak yang masih dalam usia dini akan menjadi sosok yang memiliki karakter dan mental yang handal dalam proses pembangunan bangsa.

Kompetensi sebagai seorang pendidik sangatlah penting, terlebih objek yang menjadi sasaran pekerjaanya adalah peserta didik yang diibaratkan kertas putih, guru akan menentukan apa yang hendak dituangkan dalam kertas tersebut, kualitas tergantung kepada sejauhmana guru bisa menempatkan diri sebagai pendidik yang memiliki kapasitas dan kompetensi professional dalam mengarahkan individu menjadi sosok yang memiliki karakter dan mentalitas handal dalam proses pembangunan bangsa.

Kinerja seseorang bisa diukur dengan sejauh mana ia melakukan sesuatu agar mendapat hasil. Sedangkan keberhasilan seseorag dapat diukur dengan kemampuan yang diperoleh. Oleh sebab itu seseorang bisa dikatakan berkinerja baik dengan merujuk pada penyelesaian tugas yang emban. Hal tersebut sesuai dengan pendapat para ahli yang mengatakan bahwa kinerja seseorang kaitannya dengan penilaian terhadap hasil 
kerjanya sesuai standar kinerja karena standar kinerja merupakan tolok ukur antara apa yang telah dilakukan. Dengan apa yang diharapkan sesuai dengan pekerjaan, jabatan dan tanggungjawab. ${ }^{4}$

Penilik merupakan seseorang yang diberi tugas untuk melaksanakan kegiatan penilikan pada lembaga nonformal yang salah satunya adalah Pendidikan Anak Usia Dini (PAUD) dan TK (Taman Kanak-kanak). Hal tersebut sesuai dengan Permanpan RI No 14 tahun 2010 Tentang Jabatan Fungsional Penilik dan Angka Kreditnya pasal 1 ayat 2 menyatakan bahwa penilik adalah tenaga kependidikan dengan tugas utama melakukan kegiatan pengendalian mutu dan evaluasi dampak program Pendidikan Anak Usia Dini (PAUD), Taman Kanak-kanak (TK), pendidikan kesetaraan dan keaksaraan, serta lembaga kursus pada jalur Pendidikan Nonformal dan Informal (PNFI).

Supervisi merupakan pengawasan atau pengendalian terhadap lembaga pendidikan untuk mencari solusi dan perbaikan dari permasalahan yang muncul di sekolah. Hal tersebut seperti yang telah dikemukakan oleh Nerney dalam Suyadi bahwa supervisi sebagai suatu prosedur yang memberikan arah kepada proses pengajaran yang dilengkapi dengan penilaian proses pengajaran. ${ }^{5}$ Adapun menurut pendapat Suyadi sendiri, bahwa supervisi PAUD merupakan suatu teknik yang digunakan untuk mengetahui keberhasilan manajemen lembaga PAUD yang sedang maupun yang telah dilakukan oleh para penyelenggara PAUD. Melalui kegiatan supervisi dapat diketahui apa yang dibutuhkan dan kesesuaian pengelolaan lembaga dengan standar nasional pendidikan. ${ }^{6}$

Namun permasalahan yang dihadapi saat ini adalah seberapa jauh guru PAUD dan TK dapat menjalankan tugasnya sebagai pengajar dan pelatih pada jenjang anak usia dini. Karena hasil supervisi yang diperoleh peneliti sebagai Penilik PAUD dan TK di lingkungan Korwil Bidang Pendidikan Kecamatan Kokop Kabupaten Bangkalan dalam proses pembelajaran masih kurang maksimal, yaitu mengenai alat dan perangkat pembelajaran terutama tentang Rencana Pelaksanaan Pembelajaran Harian (RPPH) sebagai kelengkapan kegiatan proses belajar mengajar. Hal tersebut sangat memprihatinkan karena RPPH termasuk kunci dalam kesuksesan pembelajaran.

Hasil penelitian terdahulu juga menunjukkan bahwa workshop dapat memberikan efek positif pada peserta di UPTD SDN Genteng 2 Bangkalan. Efek tersebut adalah meningkatnya kemampuan guru dalam menyusun RPP Tematik 1 halaman melalui workshop daring dengan variasi model jigsaw. Dari dua siklus yang dilaksanakan oleh peneliti menunjukkan adanya peningkatan kompetensi peserta workshop dalam menyusun RPP Tematik 1 halaman. ${ }^{7}$

Penelitian ini diharapkan memiliki manfaat yang mengembangkan ilmu manajemen pendidikan nonformal terutama dalam mengimplementasikan peran penilik

\footnotetext{
${ }^{4}$ Nainggolan, Peningkatan Kinerja Penilik PNFI Untuk Pemberdayaan Program PNFI Di Asahan (Jakarta: Depdiknas, 2006).

${ }^{5}$ Suyadi, Manajemen PAUD TPA-KB-TK/RA (Yogyakarta: Pustaka Pelajar, 2011).

${ }^{6}$ Suyadi.

${ }^{7}$ Zainal Arifin, "PENINGKATAN KEMAMPUAN GURU DALAM MEMBUAT RENCANA PELAKSANAAN PEMBELAJARAN (RPP) TEMATIK 1 HALAMAN MELALUI WORKSHOP DARING DENGAN VARIASI MODEL JIGSAW DI UNIT PELAKSANA TEKNIS DAERAH (UPTD) SEKOLAH DASAR (SD) NEGERI GENTENG 2 BANGKALAN," Re-JIEM (Research Journal of Islamic Education Management) 3, no. 2 (2020): 201-15, https://doi.org/10.19105/rejiem.v3i2.4722.
} 
sebagai pembina serta memberikan kajian tentang pelatihan membuat Rencana Pelaksanaan Pembelajaran Harian (RPPH) terhadap guru PAUD dan TK. Serta dapat dijadikan sebagai bahan masukan dan evaluasi terkait pembinaan pendidikan nonformal bagi penilik yang berada di lingkungan Korwil Bidang Pendidikan Kecamatan Kokop.

Berdasarkan paparan latar belakang tersebut maka dapat diidentifikasi bahwa kwalitas guru pendidikan nonformal terutama dalam Membuat Rencana Pelaksanaan Pembelajaran Harian (RPPH) masih rendah. Oleh karena itu peneliti sebagai salah satu penilik di lingkungan Korwil Bidang Pendidikan Kecamatan Kokop Kabupaten Bangkalan mengajukan program pelatihan dalam meningkatkan kinerja guru PAUD dan TK. Maka kemudian usulan tersebut mendapat tanggapan dari ketua HIMPAUDI dan IGTK serta diketahui oleh Koordinator Wilayah Bidang Pendidikan Kecamatan Kokop sehingga dalam musyawarah diputuskan untuk diadakan pelatihan membuat Rencana Pelaksanaan Pembelajaran Harian (RPPH) terhadap guru PAUD dan TK. Oleh sebab itu penelitian ini berjudul "Pelatihan Menyusun Rencana Pelaksanaan Pembelajaran Harian Dalam Meningkatkan Kinerja Guru Nonformal di Korwil Bidang Pendidikan Kecamatan Kokop Kabupaten Bangkalan”.

\section{METODE PENELITIAN}

Penelitian merupakan upaya untuk mengembangkan pengetahuan dan menguji teori. Ada beberapa langkah dalam pengembangan pengetahuan melalui penelitian, yaitu mengidentifikasi masalah penelitian, melakukan studi empiris, melakukan replika atau pengulangan, menyatukan (sintesis) dan meriview, serta mengevaluasi pelaksanaaan penelitian. Melalui tahapan tersebut akan didapatkan jawaban dari tujuan penelitian melalui cara-cara ilmiah yang dituntun oleh logika, sehingga hasil yang diperolehpun dapat diterima secara ilmiah dan logis (masuk akal). ${ }^{8}$

Penelitian ini berbentuk Penelitian Tindakan Sekolah (School Action Research), yaitu sebuah penelitian yang merupakan kerjasama antara peneliti, guru, dan kepala sekolah pendidikan nonformal yang berada di lingkungan Korwil Bidang Pendidikan Kecamatan Kokop Kabupaten Bangkalan. Hal tersebut dilakukan dalam rangka meningkatkan kinerja guru PAUD dan TK agar menjadi lebih baik dalam melaksanakan kegiatan proses pembelajaran.

Penelitian Tindakan Sekolah merupakan penelitian yang dilakukan oleh Kepala Sekolah atau Pengawas Sekolah. Fokus penelitian yang dilakukan oleh Kepala Sekolah sekitar supervisi klinis, menyangkut aspek akademik seperti proses pembelajaran yang diselenggarakan oleh guru-guru. Meningkatkan kemampuan guru dalam membuat Kriteria Ketuntasan Minimal, RPP, silabus, dan penilaian hasil belajar siswa dan lainlain. PTS dapat diartikan sebagai sebuah penelitian tindakan, atas hal-hal yang ada dalam ruang lingkup pendidikan di sekolah, sifatnya memerlukan tindakan segera, dilakukan oleh Kepala Sekolah atau Pengawas Sekolah secara berulang-ulang melalui langkah-langkah, yaitu membuat perencanaan (plan), melaksanakan (action), observasi (observation), dan refleksi (reflection), sampai pada batas keadaan yang telah ditentukan. ${ }^{9}$

\footnotetext{
8 Bachtiar S Bachri, "Meyakinkan Validitas Data Melalui Triangulasi Pada Penelitian Kualitatif," Teknologi Pendidikan 10 (2010): 46-62.

9 Mohammad Yusuf, "PENINGKATAN KEMAMPUAN GURU DALAM MENENTUKAN KRITERIA KETUNTASAN MINIMAL (KKM) MELALUI WORKSHOP DI UPTD SDN BANDA
} 
Metode yang digunakan dalam penelitian ini adalah kualitatif. Penelitian kualitatif sebagai human instrument, berfungsi menetapkan fokus penelitian, memilih informan sebagai sumber data, menilai kualitas data, analisis data, menafsirkan data dan membuat kesimpulan atas temuannya. Informan dalam metode kualitatif berkembang terus (snowball) secara bertujuan (purposive) sampai data yang dikumpulkan dianggap memuaskan atau jenuh (redundancy). Peneliti merupakan key instrument dalam mengumpulkan data, peneliti harus terjun sendiri ke lapangan secara aktif. ${ }^{10}$ Dalam tradisi kualitatif, peneliti harus menggunakan diri mereka sebagai instrumen, mengikuti asumsi-asumsi kultural sekaligus mengikuti data. ${ }^{11}$

Penelitian ini juga menggunakan metode deskriptif dengan persentase untuk melihat peningkatan yang terjadi dari siklus ke siklus. Metode deskriptif dapat diartikan sebagai prosedur pemecahan masalah yang diselidiki dengan menggambarkan atau melukiskan keadaan subjek/objek penelitian (seseorang, lembaga, masyarakat, dan lainlain) pada saat sekarang berdasarkan fakta-fakta yang tampak atau sebagaimana adanya. $^{12}$ Dengan metode ini peneliti berupaya untuk menjelaskan data yang dikumpulkan melalui pengamatan dan instrumen.

Penelitian ini bertujuan untuk memperbaiki kinerja guru PAUD dan TK agar melaksanakan kegiatan proses pembelajaran yang lebih baik. Adapun komptensi yang menjadi sasaran dalam penelitian ini adalah pembinaan yang dikemas dengan pelatihan membuat Rencana Pelaksanaan Pembelajaran Harian (RPPH) bagi guru nonformal di Korwil Bidang Pendidikan Kecamatan Kokop Kabupaten Bangkalan.

Penelitian ini dilakukan terhadap 17 lembaga yang terdiri dari 17 kepala sekolah dan 17 tenaga guru pendidikan nonformal yang berada di wilayah lingkungan Korwil Bidang Pendidikan Kecamatan Kokop Kabupaten Bangkalan dengan rincian sebagai berikut.

Tabel 1. Daftar Lembaga, Kepala Sekolah, dan Guru Pendidikan Nonformal Wilayah Binaan PAUD dan TK Di Lingkungan Korwil Bidang Pendidikan Kecamatan Kokop Kabupaten Bangkalan

\begin{tabular}{clll}
\hline No. & \multicolumn{1}{c}{ Nama Lembaga } & \multicolumn{1}{c}{$\begin{array}{c}\text { Nama Kepala } \\
\text { Sekolah }\end{array}$} & \multicolumn{1}{c}{ Nama Guru } \\
\hline 1 & TK Darul Muhibbin & Moh. Toha & Sumtin \\
\hline 2 & TK Dharma Wanita Persatuan & Nurlatipah, A.Ma & Isro'iyah \\
\hline 3 & KB Nurul Huda & Napiah & Hozanah \\
\hline 4 & Pos PAUD Miftahul Mubtadiein & Juhaeriyah & Mas'udah \\
\hline 5 & TK Ki Hajar Dewantara & Sumiati, S.Pd & Aprilia Eka Damayanti \\
\hline
\end{tabular}

SOLEH 1 KECAMATAN KOKOP KABUPATEN BANGKALAN TAHUN 2019," $R e$-JIEM (Research Journal of Islamic Education Management) 2, no. 1 (2019): 138, https://doi.org/https://doi.org/10.19105/re-jiem.v2i1.2456.

10 Imam Gunawan, Metode Penelitian Kualitatif Teori \& Praktek (Jakarta: PT. Bumi Aksara, 2014).

11 Mohammad Mulyadi, "Penelitian Kuantitatif Dan Kualitatif Serta Pemikiran Dasar Menggabungkannya," Jurnal Studi Komunikasi Dan Media 15, no. 1 (2013): 128-37, https://doi.org/10.31445/jskm.2011.150106.

12 Hadari Nawawi, Metode Penelitian Bidang Sosial (Yogyakarta: Gadjah Mada University Press, 1985). 


\begin{tabular}{|c|c|c|c|}
\hline 6 & TK Melati & Istianah & Sofiatul Fikliyah \\
\hline 7 & TK Miftahul Huda & Fatunisa' & Rohimah \\
\hline 8 & Pos PAUD Assa'idi & Jumiati, S.Pd & Rokayyah \\
\hline 9 & Pos PAUD Al Istianah & Nurlaela, S.PdI & Riskianti Rukmana \\
\hline 10 & TK Nurul Halim & Moh. Samhaji & Mohammad Cholil \\
\hline 11 & TK Nurul Hikmah & Suraji & Kutsiyah \\
\hline 12 & TK Nurul Huda & Khoiriyah, S.Pd & Khoiriyah \\
\hline 13 & KB As Salidin & Musrifah, S.PdI & Badrut Taman \\
\hline 14 & TK Al Wasilah & Komariyah, S.PdI & Bedriyeh \\
\hline 15 & KB Tarbiyatussibyan & $\begin{array}{l}\text { Zehri Hanifah, } \\
\text { S.PdI }\end{array}$ & Mardiyah \\
\hline 16 & TK Raudlatul Ma arif & Samsudin, M.PdI & Farrohah \\
\hline 17 & TK Al-Latifiyah & Hatirah & Kutiyah \\
\hline
\end{tabular}

Pelaksanaan tindakan sekolah ini dilakukan bulan April sampai bulan Mei 2021. Yaitu tanggal 5 sampai dengan 10 April 2021 adalah tahap perencanaan, tanggal 19 April 2021 prasiklus, tanggal 24 April 2021 siklus I, dan tanggal 30 April 2021 siklus II, serta pada awal Mei 2021 adalah tahap akhir penelitian. Mengapa pelaksanaan penelitian ini mengambil pada bulan-bulan tersebut, karena pada bulan tersebut adalah akhir dari pada semester II dalam tahun ajaran 2020/2021. Berkenaan dengan hal tersebut pula guru akan mengerjakan program tahunan untuk persiapan pembelajaran pada semester I tahun ajaran 2021/2022. Oleh karena itu, peneliti dapat melakukan pengamatan langsung atas pelakasanaan pelatihan yang akan diberikan kepada guru pendidikan nonformal di lingkungan Korwil Bidang Pendidikan Kecamatan Kokop Kabupatebn Bangkalan.

Teknik pengumpulan data dalam penelitian ini adalah instrumen tes yang dilakukan dengan tiga pertemuan; yaitu prasiklus, siklus I, dan siklus II. Adapun penyusunan instrumen pada dasarnya adalah menyusun alat evaluasi, karena mengevaluasi itu akan memperoleh data tentang sesuatu yang diteliti, hasil yang diperoleh dapat diukur dengan penggunaan standar yang telah ditentukan sebelumnya oleh peneliti. Dalam hal ini terdapat dua macam alat evaluasi yang dapat dikembangkan menjadi instrumen penelitian, yaitu tes dan non-tes. ${ }^{13}$ Pendapat lain juga mengatakan bahwa metode tes, instrumennya adalah soal tes akan tetapi metode observasi, instrumennya bernama cheklist. ${ }^{14}$

Adapun langkah-langkah siklus dalam ini penelitian adalah tahap perencanaan pelatihan, pelaksanaan, observasi, dan refleksi. Sedangkan acuan pelaksaaan pelatihan ini adalah observasi awal untuk mengidentifikasi masalah dan menganalisis penyebab masalah melalui pelaksanaan prasiklus pada setiap guru pendidikan nonformal dari masing-masing sekolah. Adapun indikator nilai keberhasilan dalam penelitian ini diharapkan para guru mendapat nilai rata-rata 80 dan persentase memenuhi kriteria mencapai hingga $80 \%$ dalam penilaian pelaksanaan pelatihan. Apabila nilai rata-rata

13 C. Narbuko and Ahmadi A.H., Metodologi Penelitian (Jakarta: Bumi Aksara, 2004).

14 Nick Black, Consensus Development Methods: A Review of Best Practice in Creating Clinical Guidelines (Oxford: Blackwell Publishing, 2006). 
yang diperoleh kurang dari 80 dan belum mencapai persentase memenuhi kriteria mencapai hingga $80 \%$ maka tidak memenuhi indikator yang telah ditetapkan, berarti tindakan dianggap belum berhasil. Oleh karena itu perlu dilakukan perbaikan pada siklus II.

\section{HASIL DAN PEMBAHASAN}

Penelitian tindakan sekolah yang telah dilakukan mengalami 2 kali siklus tindakan dan dinyatakan berhasil meningkatkan kemampuan guru dalam menyusun Rencana Pelaksanaan Pembelajaran Harian (RPPH) di Lingkungan Korwil Bidang Pendidikan Kecamatan Kokop Kabupaten Bangkalan. Masing-masing siklus dilaksanakan 1 kali pertemuan. Kegiatan pertemuan masing-masing siklus meliputi pertemuan pelaksanaan pelatihan mulai pemberian materi sampai penilaian hasil pelatihan. Waktu kegiatan pada bulan April 2021.

\section{Perencanaan}

Perencanaan adalah langkah awal yang dilakukan peneliti saat akan memulai tindakannya. Agar perencanaan mudah dipahami oleh objek yang melakukan tindakan, maka peneliti membuat panduan tindakan.

Adapun hal-hal yang dilakukan oleh peneliti dalam merencanakan Penelitian Tindakan Sekolah ini adalah: a) menyusun jadwal penelitian b) menyusun rencana kegiatan pertemuan dan pembinaan dengan semua kepalasa sekolah dan guru calon peserta Pelatihan di Lingkungan Korwil Bidang Pendidikan Kecamatan Kokop Kabupaten Bangkalan dalam menyusun rencana pelaksanaan pembelajaran harian $(\mathrm{RPPH})$, c) menyiapkan alat dan sumber belajar, termasuk menyiapkan tempat pertemuan, dan d) menyiapkan format penugasan penyusunan Rencana Pelaksanaan Pembelajaran Harian (RPPH) serta pedoman wawancara dan observasi tentang pelaksanaan pelatihan pada setiap siklus penelitian.

Pelaksanaan penelitian didasarkan pada jadwal kegiatan agar tersusun dan terlaksanan secara sistematis. Jadwal penelitian ini dilakukan selama tiga bulan yaitu bulan Maret sampai dengan bulan Mei 2021 mulai dari perencanaan sampai dengan penulisan laporan. Adapun rencana jadwal kegiatan penelitian yang akan dilakukan seperti tampak dalam Tabel 2 sebagai berikut.

Tabel 2. Rencana Jadwal Kegiatan Penelitian

\begin{tabular}{clccc}
\hline No & \multicolumn{1}{c}{ Kegiatan } & $\begin{array}{c}\text { Maret } \\
\mathbf{2 0 2 1}\end{array}$ & $\begin{array}{c}\text { April } \\
\mathbf{2 0 2 1}\end{array}$ & $\begin{array}{c}\text { Mei } \\
\mathbf{2 0 2 1}\end{array}$ \\
\hline 1 & Observasi awal PTS & Minggu 1-2 & & \\
\hline 2 & Perencanaan siklus & Minggu 3-4 & & Minggu 1-2 \\
\hline 3 & Pelaksanaan & & Minggu 1-4 & Minggu 1-2 \\
\hline 4 & Pengamatan & & Minggu 1-4 & Minggu 1-2 \\
\hline 5 & Refleksi & & Minggu 1-4 & Minggu 1-2 \\
\hline & Berlanjut sesuai situasi & & \\
\hline 5 & Penyusunan Laporan & & & Minggu 3-4 \\
\hline
\end{tabular}




\section{Prasiklus}

Pelatihan membuat Rencana Pelaksanaan Pembelajaran Harian (RPPH) untuk guru PAUD dan TK di lingkunganKorwil Bidang Pendidikan Kecamatan Kokop Kabupaten Bangkalan ini menindaklanjuti hasil temuan peneliti dalam supervisi bahwa RPPH yang dibuat guru di sekolah masih kurang tepat penyusunannya, oleh karena itu kemudian diadakan pelatihan membuat Rencana Pelaksanaan Pembelajaran Harian yang diawali dengan pelaksanaan prasiklus.

Prasiklus pelatihan membuat Rencana Pelaksanaan Pembelajaran Harian (RPPH) Guru PAUD dan TK di lingkunganKorwil Bidang Pendidikan Kecamatan Kokop Kabupaten Bangkalan dilaksanakan pada tanggal 19 April 2021, dalam pertemuan tersebut guru diberi materi tentang langkah-langkah penyusunan RPPH dalam mengisi kolom identitas, menentukan alokasi waktu, menentukan standar kompetensi, kompetensi dasar, dan indikator yang akan digunakan, merumuskan tujuan pembelajaran berdasarkan standar kompetensi, kompetensi dasar, dan indikator yang telah ditentukan, mengidentifikasi materi ajar berdasarkan materi pembelajaran yang terdapat dalam silabus dan materi ajar merupakan uraian dari materi pembelajaran, menentukan metode pembelajaran yang akan digunakan, merumuskan langkah-langkah pembelajaran yang terdiri dari kegiatan awal, inti, dan akhir, menentukan sumber belajar yang digunakan, menyusun kriteria penilaian, lembar pengamatan, contoh soal, dan teknik penskoran.

Aspek yang dinilai dalam pelaksanaan pelatihan ini terdiri dari 9 aspek yang dapat dilihat dalam tabel berikut.

Tabel 3. Aspek yang dinilai dalam pelatihan

\begin{tabular}{|l|l|}
\hline \multicolumn{1}{|c|}{ Aspek } & \multicolumn{1}{c|}{ Jenis Penilaian } \\
\hline Aspek 1 & Mengisi kolom identitas \\
\hline Aspek 2 & Menentukan alokasi waktu \\
\hline Aspek 3 & Menentukan standar kompetensi, kompetensi dasar dan indikator \\
\hline Aspek 4 & $\begin{array}{l}\text { Merumuskan tujuan pembelajaran berdasarkan standar kompetensi, } \\
\text { kompetensi dasar dan indikator }\end{array}$ \\
\hline Aspek 5 & Mengidentifikasi materi ajar berdasarkan silabus \\
\hline Aspek 6 & Menentukan metode pembelajaran \\
\hline Aspek 7 & Merumuskan langkah-langkah pembelajaran awal, inti, dan akhir \\
\hline Aspek 8 & Menentukan sumber belajar \\
\hline Aspek 9 & Menyusun kriteria penilaian \\
\hline \multicolumn{2}{|l|}{ Sumber: Penyusunan Rencana Pelaksanaan Pembelajaran Pendidikan Anak Usia Dini }
\end{tabular}

Adapun hasil pelaksanaan prasiklus adalah sebagai berikut.

Tabel 4. Hasil Pengukuran Pelatihan Membuat RPPH Pada Prasiklus

\begin{tabular}{|c|c|c|c|c|c|c|c|c|c|c|c|c|}
\hline \multirow[b]{2}{*}{ No } & \multirow[b]{2}{*}{ Nama } & \multicolumn{9}{|c|}{ Aspek yang dinilai } & \multirow[b]{2}{*}{$\begin{array}{l}\text { Jml. } \\
\text { nilai }\end{array}$} & \multirow{2}{*}{$\begin{array}{c}\mathbf{R e} \\
\text { rat } \\
\mathbf{a}\end{array}$} \\
\hline & & $\begin{array}{l}\text { Asp } \\
\text { ek 1 }\end{array}$ & $\begin{array}{l}\text { Asp } \\
\text { ek 2 }\end{array}$ & $\begin{array}{l}\text { Asp } \\
\text { ek 3 }\end{array}$ & $\begin{array}{l}\text { Asp } \\
\text { ek } 4\end{array}$ & $\begin{array}{l}\text { Asp } \\
\text { ek 5 }\end{array}$ & $\begin{array}{l}\text { Asp } \\
\text { ek 6 }\end{array}$ & $\begin{array}{l}\text { Asp } \\
\text { ek } 7\end{array}$ & $\begin{array}{l}\text { Asp } \\
\text { ek 8 }\end{array}$ & $\begin{array}{l}\text { Asp } \\
\text { ek 9 }\end{array}$ & & \\
\hline 1 & Moh. Toha & 65 & 70 & 80 & 65 & 70 & 60 & 65 & 70 & 65 & 610 & 68 \\
\hline 2 & Nurlatipah & 70 & 75 & 70 & 65 & 75 & 60 & 60 & 75 & 75 & 625 & 69 \\
\hline 3 & Napiah & 75 & 65 & 75 & 70 & 65 & 60 & 65 & 65 & 65 & 605 & 67 \\
\hline
\end{tabular}




\begin{tabular}{|c|c|c|c|c|c|c|c|c|c|c|c|c|}
\hline 4 & Juhaeriyah & 65 & 70 & 65 & 75 & 70 & 70 & 65 & 70 & 65 & 615 & 68 \\
\hline 5 & Sumiati & 70 & 65 & 70 & 65 & 65 & 60 & 65 & 65 & 70 & 595 & 66 \\
\hline 6 & Istianah & 65 & 70 & 65 & 70 & 70 & 60 & 65 & 70 & 75 & 610 & 68 \\
\hline 7 & Fatunisa' & 70 & 75 & 70 & 65 & 75 & 60 & 60 & 75 & 65 & 615 & 68 \\
\hline 8 & Jumiati & 75 & 60 & 75 & 70 & 65 & 60 & 65 & 65 & 70 & 605 & 67 \\
\hline 9 & Nurlaela & 70 & 60 & 65 & 75 & 65 & 65 & 70 & 75 & 65 & 610 & 68 \\
\hline 10 & Moh. Samhaji & 65 & 70 & 75 & 75 & 75 & 65 & 75 & 65 & 70 & 635 & 71 \\
\hline 11 & Suraji & 70 & 75 & 65 & 65 & 65 & 65 & 65 & 65 & 75 & 610 & 68 \\
\hline 12 & Khoiriyah & 75 & 65 & 70 & 70 & 65 & 70 & 70 & 65 & 65 & 615 & 68 \\
\hline 13 & Musrifah & 65 & 70 & 75 & 75 & 65 & 75 & 65 & 65 & 75 & 630 & 70 \\
\hline 14 & Komariyah & 75 & 65 & 65 & 65 & 70 & 65 & 70 & 75 & 75 & 625 & 69 \\
\hline 15 & Zehri Hanifah & 65 & 70 & 70 & 70 & 75 & 70 & 75 & 65 & 65 & 625 & 69 \\
\hline 16 & Samsudin & 75 & 75 & 65 & 80 & 65 & 65 & 75 & 75 & 75 & 650 & 72 \\
\hline 17 & Hatirah & 70 & 60 & 70 & 70 & 70 & 70 & 65 & 70 & 65 & 610 & 68 \\
\hline 18 & Sumtin & 75 & 60 & 75 & 75 & 65 & 75 & 65 & 75 & 65 & 630 & 70 \\
\hline 19 & Isro'iyah & 65 & 60 & 65 & 80 & 70 & 60 & 65 & 65 & 65 & 595 & 66 \\
\hline 20 & Hozanah & 70 & 60 & 75 & 70 & 75 & 60 & 70 & 70 & 65 & 615 & 68 \\
\hline 21 & Mas'udah & 65 & 60 & 65 & 75 & 75 & 65 & 75 & 65 & 75 & 620 & 69 \\
\hline 22 & Aprilia E. D. & 70 & 70 & 80 & 65 & 55 & 65 & 65 & 70 & 65 & 605 & 67 \\
\hline 23 & Sofiatul F. & 75 & 75 & 65 & 70 & 70 & 65 & 70 & 75 & 75 & 640 & 71 \\
\hline 24 & Rohimah & 70 & 65 & 75 & 75 & 75 & 65 & 65 & 65 & 70 & 625 & 69 \\
\hline 25 & Rokayyah & 75 & 70 & 65 & 70 & 65 & 70 & 70 & 70 & 75 & 630 & 70 \\
\hline 26 & Riskianti R. & 65 & 65 & 80 & 75 & 70 & 75 & 75 & 75 & 65 & 645 & 72 \\
\hline 27 & Mohammad C. & 70 & 70 & 60 & 70 & 65 & 65 & 70 & 65 & 70 & 605 & 67 \\
\hline 28 & Kutsiyah & 65 & 70 & 70 & 75 & 70 & 70 & 75 & 70 & 65 & 630 & 70 \\
\hline 29 & Khoiriyah & 70 & 65 & 75 & 65 & 75 & 65 & 65 & 65 & 70 & 615 & 68 \\
\hline 30 & Badrut Taman & 75 & 70 & 65 & 65 & 65 & 70 & 70 & 70 & 75 & 625 & 69 \\
\hline 31 & Bedriyeh & 65 & 75 & 70 & 65 & 65 & 75 & 65 & 75 & 65 & 620 & 69 \\
\hline 32 & Mardiyah & 55 & 65 & 65 & 65 & 65 & 65 & 70 & 65 & 65 & 580 & 64 \\
\hline 33 & Farrohah & 65 & 75 & 70 & 75 & 65 & 70 & 75 & 65 & 65 & 625 & 69 \\
\hline 34 & Kutiyah & 65 & 65 & 75 & 75 & 75 & 75 & 65 & 75 & 75 & 645 & 72 \\
\hline \multicolumn{2}{|c|}{$\begin{array}{l}\text { Persentase memenuhi } \\
\text { kriteria }\end{array}$} & $59 \%$ & $53 \%$ & $60 \%$ & $73 \%$ & $53 \%$ & $39 \%$ & $45 \%$ & $55 \%$ & $50 \%$ & & \\
\hline \multicolumn{2}{|c|}{$\begin{array}{l}\text { Persentase tidak memenuhi } \\
\text { kriteria }\end{array}$} & $41 \%$ & $47 \%$ & $40 \%$ & $27 \%$ & $47 \%$ & $61 \%$ & $55 \%$ & $45 \%$ & $50 \%$ & & \\
\hline
\end{tabular}

Hasil pelaksanaan prasiklus ini para guru dan kepala sekolah hanya mampu mendapat nilai rata-rata 64 hingga 72 setiap individu. Sedangkan hasil dari persentase adalah sebagai berikut. Dalam aspek mengisi kolom identitas berkisar 59\% guru dan kepala sekolah memenuhi kriteria, sedangkan $41 \%$ tidak memenuhi kriteria. Pada aspek menentukan alokasi waktu sekitar 53\% guru dan kepala sekolah memenuhi kriteria, dan $47 \%$ tidak memenuhi kriteria. Pada aspek menentukan SK, KD, dan indikator $60 \%$ guru dan kepala sekolah memenuhi kriteria, dan 40\% tidak memenuhi kriteria. Pada aspek merumuskan tujuan pembelajaran berdasarkan standar kompetensi, kompetensi dasar, dan indikator $73 \%$ guru dan kepala sekolah memenuhi kriteria, dan $27 \%$ tidak memenuhi kriteria. Pada aspek mengidentifikasi materi ajar berdasarkan silabus 53\% guru dan kepala sekolah memenuhi kriteria, dan $47 \%$ tidak memenuhi kriteria. Pada 
aspek menentukan metode pembelajaran 39\% guru dan kepala sekolah memenuhi kriteria, dan $61 \%$ tidak memenuhi kriteria. Pada aspek merumuskan langkah-langkah pembelajaran dari kegiatan awal, inti, dan akhir $45 \%$ guru dan kepala sekolah memenuhi kriteria, dan 55\% tidak memenuhi kriteria. Pada aspek menentukan sumber belajar 55\% guru dan kepala sekolah memenuhi kriteria, dan 45\% tidak memenuhi kriteria. Dan pada aspek menyusun kriteria penilaian $50 \%$ guru dan kepala sekolah memenuhi kriteria, dan 50\% tidak memenuhi kriteria.

\section{Siklus I}

Siklus I ini dilaksanakan pada tanggal 24 April 2021, dalam pelaksanaan tersebut guru kembali diberi materi tentang penyusunan Rencana Pelaksanaan Pembelajaran Harian yang terdiri dari identitas mata pelajaran, standar kompetensi, kompetensi dasar, indikator pencapaian kompetensi, tujuan pembelajaran, karakter yang diharapkan, materi ajar, alokasi waktu, metode pembelajaran, kegiatan pembelajaran, penilaian hasil belajar.

Adapun hasil siklus I adalah sebagai berikut.

Tabel 5. Hasil Pengukuran Pelatihan Membuat RPPH Pada Siklus I

\begin{tabular}{|c|c|c|c|c|c|c|c|c|c|c|c|c|}
\hline \multirow[b]{2}{*}{ No } & \multirow[b]{2}{*}{ Nama } & \multicolumn{9}{|c|}{ Aspek yang dinilai } & \multirow{2}{*}{$\begin{array}{l}\text { Jml. } \\
\text { nilai }\end{array}$} & \multirow{2}{*}{$\begin{array}{l}\text { Rer } \\
\text { ata }\end{array}$} \\
\hline & & $\begin{array}{l}\text { Asp } \\
\text { ek 1 }\end{array}$ & $\begin{array}{l}\text { Asp } \\
\text { ek } 2\end{array}$ & $\begin{array}{l}\text { Asp } \\
\text { ek 3 }\end{array}$ & $\begin{array}{l}\text { Asp } \\
\text { ek } 4\end{array}$ & $\begin{array}{l}\text { Asp } \\
\text { ek } 5\end{array}$ & $\begin{array}{l}\text { Asp } \\
\text { ek } 6\end{array}$ & $\begin{array}{l}\text { Asp } \\
\text { ek } 7\end{array}$ & $\begin{array}{l}\text { Asp } \\
\text { ek 8 }\end{array}$ & $\begin{array}{l}\text { Asp } \\
\text { ek 99 }\end{array}$ & & \\
\hline 1 & Moh. Toha & 85 & 75 & 85 & 75 & 80 & 75 & 75 & 80 & 80 & 710 & 79 \\
\hline 2 & Nurlatipah & 85 & 80 & 80 & 65 & 80 & 65 & 80 & 80 & 80 & 695 & 77 \\
\hline 3 & Napiah & 90 & 65 & 75 & 80 & 75 & 75 & 75 & 75 & 65 & 675 & 75 \\
\hline 4 & Juhaeriyah & 65 & 75 & 65 & 75 & 80 & 80 & 80 & 80 & 75 & 675 & 75 \\
\hline 5 & Sumiati & 80 & 65 & 70 & 65 & 65 & 65 & 75 & 65 & 80 & 630 & 70 \\
\hline 6 & Istianah & 65 & 80 & 65 & 80 & 80 & 65 & 75 & 75 & 75 & 660 & 73 \\
\hline 7 & Fatunisa' & 90 & 70 & 75 & 65 & 80 & 75 & 75 & 80 & 65 & 675 & 75 \\
\hline 8 & Jumiati & 80 & 65 & 80 & 80 & 75 & 65 & 65 & 65 & 80 & 655 & 73 \\
\hline 9 & Nurlaela & 90 & 65 & 65 & 75 & 65 & 75 & 80 & 80 & 75 & 670 & 74 \\
\hline 10 & Moh. Samhaji & 80 & 70 & 75 & 80 & 80 & 65 & 75 & 70 & 80 & 675 & 75 \\
\hline 11 & Suraji & 90 & 75 & 65 & 65 & 65 & 65 & 65 & 75 & 75 & 640 & 71 \\
\hline 12 & Khoiriyah & 80 & 65 & 80 & 80 & 65 & 80 & 80 & 80 & 65 & 675 & 75 \\
\hline 13 & Musrifah & 65 & 75 & 75 & 80 & 65 & 80 & 65 & 65 & 80 & 650 & 72 \\
\hline 14 & Komariyah & 80 & 65 & 65 & 65 & 80 & 65 & 80 & 80 & 75 & 655 & 73 \\
\hline 15 & Zehri Hanifah & 65 & 70 & 80 & 80 & 80 & 80 & 80 & 65 & 65 & 665 & 74 \\
\hline 16 & Samsudin & 80 & 75 & 65 & 80 & 65 & 65 & 75 & 80 & 75 & 660 & 73 \\
\hline 17 & Hatirah & 85 & 80 & 80 & 80 & 70 & 75 & 65 & 70 & 80 & 685 & 76 \\
\hline 18 & Sumtin & 90 & 65 & 80 & 75 & 65 & 80 & 75 & 75 & 80 & 685 & 76 \\
\hline 19 & Isro'iyah & 80 & 70 & 75 & 85 & 80 & 80 & 80 & 75 & 65 & 690 & 77 \\
\hline 20 & Hozanah & 80 & 70 & 85 & 80 & 80 & 80 & 80 & 80 & 65 & 700 & 78 \\
\hline 21 & Mas'udah & 90 & 75 & 65 & 75 & 80 & 75 & 80 & 65 & 80 & 685 & 76 \\
\hline 22 & Aprilia E. D. & 65 & 80 & 80 & 65 & 65 & 80 & 65 & 80 & 65 & 645 & 72 \\
\hline 23 & Sofiatul F. & 80 & 80 & 65 & 80 & 80 & 75 & 80 & 80 & 75 & 695 & 77 \\
\hline 24 & Rohimah & 85 & 65 & 80 & 75 & 80 & 80 & 65 & 75 & 80 & 685 & 76 \\
\hline 25 & Rokayyah & 80 & 80 & 65 & 80 & 65 & 80 & 80 & 80 & 80 & 690 & 77 \\
\hline 26 & Riskianti R. & 80 & 65 & 80 & 80 & 80 & 85 & 85 & 85 & 65 & 705 & 78 \\
\hline
\end{tabular}




\begin{tabular}{|c|c|c|c|c|c|c|c|c|c|c|c|c|}
\hline 27 & Mohammad C. & 85 & 75 & 65 & 75 & 65 & 65 & 80 & 65 & 75 & 650 & 72 \\
\hline 28 & Kutsiyah & 80 & 80 & 75 & 80 & 80 & 75 & 80 & 80 & 75 & 705 & 78 \\
\hline 29 & Khoiriyah & 80 & 65 & 80 & 65 & 75 & 65 & 65 & 65 & 80 & 640 & 71 \\
\hline 30 & Badrut Taman & 90 & 80 & 80 & 75 & 80 & 80 & 80 & 80 & 75 & 720 & 80 \\
\hline 31 & Bedriyeh & 65 & 90 & 75 & 65 & 80 & 90 & 75 & 80 & 65 & 685 & 76 \\
\hline 32 & Mardiyah & 65 & 65 & 75 & 80 & 75 & 65 & 80 & 80 & 80 & 665 & 74 \\
\hline 33 & Farrohah & 65 & 80 & 80 & 90 & 80 & 80 & 80 & 75 & 80 & 710 & 79 \\
\hline 34 & Kutiyah & 65 & 75 & 80 & 80 & 80 & 75 & 80 & 80 & 80 & 695 & 77 \\
\hline \multicolumn{2}{|c|}{$\begin{array}{l}\text { Persentase memenuhi } \\
\text { kriteria }\end{array}$} & $74 \%$ & $68 \%$ & $71 \%$ & $77 \%$ & $71 \%$ & $68 \%$ & $80 \%$ & $80 \%$ & $74 \%$ & & \\
\hline \multicolumn{2}{|c|}{$\begin{array}{l}\text { Persentase tidak memenuhi } \\
\text { kriteria }\end{array}$} & $26 \%$ & $32 \%$ & $29 \%$ & $23 \%$ & $29 \%$ & $32 \%$ & $20 \%$ & $20 \%$ & $26 \%$ & & \\
\hline
\end{tabular}

Sumber: Hasil evaluasi pada siklus I

Dalam pelaksanaan siklus I ditemukan bahwa kinerja guru mulai meningkat, hal tersebut terlihat dari hasil siklus I. Hasil pelaksanaan siklus I ini para guru dan kepala sekolah mampu mendapat nilai rata-rata 70 hingga 80 setiap individu. Sedangkan hasil dari persentase adalah sebagai berikut. Dalam aspek mengisi kolom identitas berkisar 74\% guru dan kepala sekolah memenuhi kriteria, sedangkan 26\% tidak memenuhi kriteria. Pada aspek menentukan alokasi waktu sekitar 68\% guru dan kepala sekolah memenuhi kriteria, dan 32\% tidak memenuhi kriteria. Pada aspek menentukan SK, KD, dan indikator $71 \%$ guru dan kepala sekolah memenuhi kriteria, dan $29 \%$ tidak memenuhi kriteria. Pada aspek merumuskan tujuan pembelajaran berdasarkan standar kompetensi, kompetensi dasar, dan indikator $77 \%$ guru dan kepala sekolah memenuhi kriteria, dan 23\% tidak memenuhi kriteria. Pada aspek mengidentifikasi materi ajar berdasarkan silabus $71 \%$ guru dan kepala sekolah memenuhi kriteria, dan $29 \%$ tidak memenuhi kriteria. Pada aspek menentukan metode pembelajaran $68 \%$ guru dan kepala sekolah memenuhi kriteria, dan 32\% tidak memenuhi kriteria. Pada aspek merumuskan langkah-langkah pembelajaran dari kegiatan awal, inti, dan akhir 80\% guru dan kepala sekolah memenuhi kriteria, dan 20\% tidak memenuhi kriteria. Pada aspek menentukan sumber belajar $80 \%$ memenuhi kriteria, dan $20 \%$ tidak memenuhi kriteria. Dan pada aspek menyusun kriteria penilaian $74 \%$ guru dan kepala sekolah memenuhi kriteria, dan 26\% tidak memenuhi kriteria. Pada siklus I ini para guru dan kepala sekolah PAUD dan TK belum mampu membuat RPPH dengan baik serta belum memenuhi kriteria yang diharapkan, oleh karena itu pelatihan dilanjut pada siklus berikutnya.

\section{Siklus II}

Siklus II dilaksanakan pada tanggal 30 April 2021, dalam pelaksanaan siklus tersebut guru kembali diberi pemantapan materi seperti prasiklus dan siklus I. Pada pelaksanaan siklus II ini ditemukan bahwa kinerja guru dan kepala sekolah semakin meningkat, hal tersebut terlihat dari hasil siklus II, yaitu sebagai berikut.

Tabel 6. Hasil Pengukuran Pelatihan Membuat RPPH Pada Siklus II

\begin{tabular}{|c|c|c|c|c|c|c|c|c|c|c|c|c|}
\hline \multirow[b]{2}{*}{ No } & \multirow[b]{2}{*}{ Nama } & \multicolumn{9}{|c|}{ Aspek yang dinilai } & \multirow[b]{2}{*}{$\begin{array}{l}\text { Jml. } \\
\text { nilai }\end{array}$} & \multirow{2}{*}{$\begin{array}{c}\mathrm{Re} \\
\text { rat } \\
\mathbf{a}\end{array}$} \\
\hline & & $\begin{array}{c}\text { Aspek } \\
1\end{array}$ & $\begin{array}{l}\text { Asp } \\
\text { ek 2 }\end{array}$ & $\begin{array}{l}\text { Asp } \\
\text { ek 3 }\end{array}$ & $\begin{array}{l}\text { Asp } \\
\text { ek } 4\end{array}$ & $\begin{array}{l}\text { Asp } \\
\text { ek } 5\end{array}$ & $\begin{array}{l}\text { Asp } \\
\text { ek } 6\end{array}$ & $\begin{array}{c}\text { Aspek } \\
7 \\
\end{array}$ & $\begin{array}{l}\text { Asp } \\
\text { ek 8 }\end{array}$ & $\begin{array}{c}\text { Aspek } \\
9\end{array}$ & & \\
\hline 1 & Moh. Toha & 90 & 90 & 85 & 95 & 85 & 95 & 90 & 95 & 85 & 810 & 90 \\
\hline 2 & Nurlatipah & 95 & 85 & 85 & 90 & 95 & 65 & 90 & 85 & 90 & 780 & 87 \\
\hline
\end{tabular}




\begin{tabular}{|c|c|c|c|c|c|c|c|c|c|c|c|c|}
\hline 3 & Napiah & 95 & 90 & 90 & 90 & 90 & 95 & 90 & 90 & 90 & 820 & 91 \\
\hline 4 & Juhaeriyah & 90 & 90 & 90 & 95 & 90 & 90 & 90 & 90 & 85 & 810 & 90 \\
\hline 5 & Sumiati & 90 & 90 & 85 & 95 & 65 & 65 & 90 & 65 & 85 & 730 & 81 \\
\hline 6 & Istianah & 95 & 90 & 90 & 90 & 90 & 90 & 95 & 90 & 90 & 820 & 91 \\
\hline 7 & Fatunisa' & 90 & 90 & 90 & 90 & 90 & 90 & 95 & 90 & 90 & 815 & 91 \\
\hline 8 & Jumiati & 90 & 85 & 85 & 90 & 90 & 65 & 85 & 90 & 85 & 765 & 85 \\
\hline 9 & Nurlaela & 95 & 90 & 65 & 95 & 65 & 90 & 90 & 90 & 90 & 770 & 86 \\
\hline 10 & Moh. Samhaji & 95 & 95 & 90 & 90 & 90 & 85 & 95 & 95 & 95 & 830 & 92 \\
\hline 11 & Suraji & 90 & 90 & 90 & 90 & 65 & 90 & 90 & 90 & 90 & 785 & 87 \\
\hline 12 & Khoiriyah & 90 & 90 & 90 & 95 & 85 & 90 & 90 & 90 & 85 & 805 & 89 \\
\hline 13 & Musrifah & 90 & 95 & 90 & 90 & 95 & 95 & 95 & 95 & 95 & 840 & 93 \\
\hline 14 & Komariyah & 90 & 85 & 85 & 95 & 90 & 90 & 90 & 85 & 85 & 795 & 88 \\
\hline 15 & Zehri Hanifah & 95 & 90 & 85 & 90 & 90 & 90 & 95 & 90 & 90 & 815 & 91 \\
\hline 16 & Samsudin & 95 & 90 & 85 & 90 & 90 & 95 & 95 & 85 & 90 & 815 & 91 \\
\hline 17 & Hatirah & 95 & 90 & 85 & 90 & 90 & 85 & 90 & 90 & 85 & 800 & 89 \\
\hline 18 & Sumtin & 95 & 90 & 90 & 90 & 90 & 90 & 90 & 90 & 90 & 815 & 91 \\
\hline 19 & Isro'iyah & 90 & 90 & 90 & 95 & 85 & 85 & 90 & 90 & 85 & 800 & 89 \\
\hline 20 & Hozanah & 95 & 85 & 90 & 90 & 85 & 85 & 90 & 90 & 90 & 800 & 89 \\
\hline 21 & Mas'udah & 95 & 90 & 90 & 90 & 90 & 90 & 90 & 90 & 90 & 815 & 91 \\
\hline 22 & Aprilia E. D. & 95 & 85 & 85 & 65 & 65 & 90 & 95 & 90 & 85 & 755 & 84 \\
\hline 23 & Sofiatul F. & 95 & 85 & 65 & 95 & 90 & 90 & 95 & 95 & 95 & 805 & 89 \\
\hline 24 & Rohimah & 90 & 85 & 85 & 85 & 85 & 95 & 95 & 95 & 85 & 800 & 89 \\
\hline 25 & Rokayyah & 90 & 95 & 90 & 90 & 85 & 95 & 90 & 90 & 90 & 815 & 91 \\
\hline 26 & Riskianti R. & 90 & 95 & 95 & 90 & 90 & 95 & 95 & 90 & 80 & 820 & 91 \\
\hline 27 & Mohammad C. & 90 & 95 & 65 & 90 & 90 & 90 & 90 & 85 & 85 & 780 & 87 \\
\hline 28 & Kutsiyah & 90 & 95 & 95 & 90 & 90 & 95 & 90 & 85 & 85 & 815 & 91 \\
\hline 29 & Khoiriyah & 90 & 65 & 95 & 90 & 90 & 95 & 90 & 85 & 85 & 785 & 87 \\
\hline 30 & Badrut Taman & 95 & 90 & 90 & 90 & 90 & 90 & 90 & 90 & 90 & 815 & 91 \\
\hline 31 & Bedriyeh & 95 & 95 & 90 & 65 & 80 & 85 & 90 & 85 & 85 & 770 & 86 \\
\hline 32 & Mardiyah & 90 & 65 & 90 & 90 & 90 & 90 & 90 & 90 & 95 & 790 & 88 \\
\hline 33 & Farrohah & 95 & 85 & 90 & 90 & 85 & 85 & 85 & 85 & 90 & 790 & 88 \\
\hline 34 & Kutiyah & 90 & 85 & 85 & 90 & 90 & 95 & 95 & 90 & 95 & 815 & 91 \\
\hline \multicolumn{2}{|c|}{$\begin{array}{l}\text { Persentase memenuhi } \\
\text { kriteria }\end{array}$} & $100 \%$ & $95 \%$ & $92 \%$ & $95 \%$ & $89 \%$ & $92 \%$ & $100 \%$ & $98 \%$ & $100 \%$ & & \\
\hline \multicolumn{2}{|c|}{$\begin{array}{l}\text { Persentase tidak } \\
\text { memenuhi kriteria }\end{array}$} & $0 \%$ & $5 \%$ & $8 \%$ & $5 \%$ & $11 \%$ & $8 \%$ & $0 \%$ & $2 \%$ & $0 \%$ & & \\
\hline
\end{tabular}

Sumber: Hasil evaluasi pada siklus II

Hasil pelaksanaan siklus II ini para guru dan kepala sekolah mampu mendapat nilai rata-rata 80 hingga 90 setiap individu. Sedangkan hasil dari persentase dalam aspek mengisi kolom identitas berkisar $100 \%$ guru dan kepala sekolah memenuhi kriteria, sedangkan 0\% tidak memenuhi kriteria. Pada aspek menentukan alokasi waktu sekitar 95\% guru dan kepala sekolah memenuhi kriteria, dan 5\% tidak memenuhi kriteria. Pada aspek menentukan SK, KD, dan indikator 92\% guru dan kepala sekolah memenuhi kriteria, dan $8 \%$ tidak memenuhi kriteria. Pada aspek merumuskan tujuan pembelajaran berdasarkan standar kompetensi, kompetensi dasar, dan indikator $95 \%$ guru dan kepala sekolah memenuhi kriteria, dan 5\% tidak memenuhi kriteria. Pada aspek mengidentifikasi materi ajar berdasarkan silabus $89 \%$ guru dan kepala sekolah 
memenuhi kriteria, dan $11 \%$ tidak memenuhi kriteria. Pada aspek menentukan metode pembelajaran $92 \%$ guru dan kepala sekolah memenuhi kriteria, dan $8 \%$ tidak memenuhi kriteria. Pada aspek merumuskan langkah-langkah pembelajaran dari kegiatan awal, inti, dan akhir $100 \%$ guru dan kepala sekolah memenuhi kriteria, dan 0\% tidak memenuhi kriteria. Pada aspek menentukan sumber belajar 98\% guru dan kepala sekolah memenuhi kriteria, dan 2\% tidak memenuhi kriteria. Dan pada aspek menyusun kriteria penilaian $100 \%$ guru dan kepala sekolah memenuhi kriteria, dan 0\% tidak memenuhi kriteria. Dari hasil siklus II tersebut telah tercapai tujuan pelaksanaan pelatihan membuat RPPH, oleh karena itu siklus dihentikan.

\section{Pembahasan}

Guru, kepala sekolah, pengawas sekolah merupakan pelaku pendidikan di sekolah. Oleh karena itu kemampuan dibidangnya antara ketiganya harus berimbang agar tujuan pendidikan secara umum maupun secara khusus di sekolah bisa tercapai. Guru merupakan salah satu pelaku pendidikan di sekolah mempunyai tugas utama yaitu mengajar. Kemampuan mengajar merupakan kemampuan esensial yang harus dimiliki oleh seorang guru. Menurut undangundang nomor 14 tahun 2005 tentang guru dan dosen ada 4 kompetensi (kemampuan) dasar yang harus dimiliki oleh seorang guru profesional. 4 kemampuan dasar yang dimaksud adalah kemampuan paedagogik, profesional, sosial, dan kepribadian. ${ }^{15}$

Berawal dari hasil temuan peneliti dalam supervisi di sekolah nonformal PAUD dan TK, di lingkungan Korwil Bidang Pendidikan Kecamatan Kokop Kabupaten Bangkalan pada semester II tahun ajaran 2019/2020, yaitu guru masih kurang tepat dalam penyusunan RPPH, maka kemudian diadakan pelatihan membuat RPPH yang diawali dengan pelaksanaan prasiklus yang dilaksanakan pada tanggal 19 April 2021. Adapun hasil pelaksanaan prasiklus tersebut para guru dan kepala sekolah belum mampu membuat RPPH dengan baik.

Setelah lembar soal dikoreksi, para guru dan kepala sekolah hanya mampu mendapat nilai rata-rata 64 hingga 72 setiap individu. Sedangkan hasil dari persentase dalam aspek mengisi kolom identitas hanya berkisar 59\% guru dan kepala sekolah memenuhi kriteria, sedangkan $41 \%$ tidak memenuhi kriteria. persentase ini belum cukup memuaskan. Artinya, guru masih harus dibina dalam mengisi kolom identitas. Pada aspek menentukan alokasi waktu sekitar 53\% guru dan kepala sekolah memenuhi kriteria, dan $47 \%$ tidak memenuhi kriteria. Dari nilai ini juga belum cukup memuaskan. Artinya, guru juga masih perlu pembinaan dalam menetukan alokasi waktu. Pada aspek menentukan SK, KD, dan indikator, berkisar $60 \%$ guru dan kepala sekolah memenuhi kriteria, dan 40\% tidak memenuhi kriteria. Hasil ini juga kurang memuaskan. Artinya, guru sangat perlu untuk belajar menentukan standar kompetensi, kompetensi dasar, dan indikator. Karena standar kompetensi merupakan kualifikasi kemampuan minimal peserta didik yang menggambarkan penguasaan pengetahuan, sikap, dan keterampilan yang diharapkan pada setiap kelas pada suatu mata pelajaran. Sdangkan kompetensi dasar adalah sejumlah kemampuan yang harus dikuasai peserta didik dalam mata

15 Atik Sulistiatik, "UPAYA PENINGKATAN KEMAMPUAN GURU SMA DALAM MELAKSANAKAN PEMBELAJARAN MELALUI SUPERVISI AKADEMIK DI SEKOLAH BINAAN KABUPATEN BANGKALAN," Re-JIEM (Research Journal of Islamic Education Management) 2, no. 1 (2019): 119-30, https://doi.org/https://doi.org/10.19105/re-jiem.v2i1.2455. 
pelajaran tertentu sebagai rujukan penyusunan indikator kompetensi dalam suatu pelajaran. Adapun indikator kompetensi adalah perilaku yang dapat diukur untuk menunjukkan ketercapaian kompetensi dasar tertentu yang menjadi acuan penilaian mata pelajaran. Indikator pencapaian kompetensi dirumuskan dengan menggunakan kata kerja operasional yang dapat diukur, yang mencakup pengetahuan, sikap, dan keterampilan. Dalam aspek merumuskan tujuan pembelajaran berdasarkan standar kompetensi, kompetensi dasar, dan indikator berkisar 73\% guru dan kepala sekolah memenuhi kriteria, dan 27\% tidak memenuhi kriteria. Dalam hal ini perolehan nilai para guru dan kepala sekolah cukup memuaskan. Namun peningkatan harus dilakukan untuk memenuhi pencapaian kriteria seorang pendidik. Dari aspek mengidentifikasi materi ajar berdasarkan silabus berkisar 53\% guru dan kepala sekolah memenuhi kriteria, dan 47\% tidak memenuhi kriteria, dalam aspek ini sangat memerlukan pembinaan untuk meningkatkan kinerja guru dalam mengidentifikasi materi yang sesuai dengan silabus. Adapun dari aspek menentukan metode pembelajaran berkisar 39\% guru dan kepala sekolah memenuhi kriteria, dan 61\% tidak memenuhi kriteria. Dalam aspek ini nilai yang diperoleh sangat tidak memuaskan, oleh karena itu sangat perlu diadakan pembinaan untuk memantapkan para guru dalam melakukan pemilihan metode pembelajaran yang tepat. Adapun dari aspek merumuskan langkah-langkah pembelajaran dari kegiatan awal, inti, dan akhir berkisar $45 \%$ guru dan kepala sekolah memenuhi kriteria, dan 55\% tidak memenuhi kriteria. Perolehan nilai ini juga tidak memuaskan, oleh karena itu harus dilakukan pembinaan lebih lanjut. Sedangkan dalam aspek menentukan sumber belajar sekitar 55\% memenuhi kriteria, dan 45\% tidak memenuhi kriteria. Dalam hal ini para guru juga masih kurang peka dalam memahami alat dan bahan pembelajaran, oleh karena itu perlu diadakan pembainaan yang lebih matang untuk meningkatkan profesinal guru dalam memilih dan memilah alat pembelajaran yang tepat. Yang terakhir adalah dari aspek menyusun kriteria penilaian, hal tersebut berkisar 50\% guru dan kepala sekolah memenuhi kriteria, dan 50\% tidak memenuhi kriteria. Dalam aspek penilaian ini, pada masa sekarang ini memang sangat perlu diperbanyak sosialisasi, baik ditingkat sekolah maupun di tingkat HIMPAUDI, karena perubahan dari kurikulum KTSP ke kurikulum 2013 sangat menyita tenaga guru untuk membuat penilaian. Karena penilaian KTSP dan kurikulum 2013 sangat jauh berbeda, jika KTSP memberi penilaian cukup dengan angka, akan tetapi jika penilaian kurikulun 2013 harus melalui rumus-rumus yang juga dinarasikan.

Hasil yang diperoleh dalam prasiklus ini sangat kurang memuaskan. Maka berdasar hasil dari prasiklus ini lebih jelas bahwa RPPH yang dibuat guru di sekolah kurang tepat. Oleh karena itu harus diadakan pelatihan membuat RPPH lanjutan.

\section{Siklus I}

Dalam pelaksanaan siklus I ditemukan bahwa kinerja guru pendidikan nonformal mulai meningkat, hal tersebut terlihat dari hasil siklus I. Pertemuan siklus I dilaksanakan pada tanggal 24 April 2021. Adapun hasil siklus I dari aspek mengisi kolom identitas berkisar $74 \%$ guru dan kepala sekolah memenuhi kriteria, sedangkan 26\% tidak memenuhi kriteria. Hasil pada aspek ini kemampuan para guru dan kepala sekolah mulai meningkat. Artinya, guru yang pada prasiklus belum mampu dapat memperbaiki pada siklus I, dengan kata lain guru sudah bisa mengisi kolom identitas dengan benar, namun masih perlu ditingkatkan. Pada aspek menentukan alokasi waktu 
sekitar $68 \%$ guru dan kepala sekolah memenuhi kriteria, dan 32\% tidak memenuhi kriteria. Dalam aspek ini juga ada peningkatan jika dibandingkan dengan prasiklus, karena pada siklus I meningkat, artinya dalam menetukan alokasi waktu para guru sudah bisa menetukan dengan benar, akan tetapi juga masih perlu ditingkatkan lagi untuk pemenuhan target. Dalam aspek menentukan standar kompetensi, kompetensi dasar, dan indikator, berkisar 71\% guru dan kepala sekolah memenuhi kriteria, dan 29\% tidak memenuhi kriteria. Dalam aspek ini juga ada peningkatan yang signifikan. Karena pada tahap prasiklus hanya $60 \%$ guru dan kepala sekolah memenuhi kriteria, namun dalam siklus I para guru mencapai $71 \%$ dapat menentukan standar kompetensi, kompetensi dasar, dan indikator. Dalam aspek ini para guru antusias untuk mengikuti materi, karena memang materi ini yang sangat ditekankan kepada para pendidik. Adapun dari aspek merumuskan tujuan pembelajaran berdasarkan standar kompetensi, kompetensi dasar, dan indikator $77 \%$ guru dan kepala sekolah memenuhi kriteria, dan 23\% tidak memenuhi kriteria. Pada penilaian aspek ini juga meningkat. Karena pada prasiklus para guru hanya berkisar $73 \%$ guru dan kepala sekolah memenuhi kriteria, namun pada siklus I meningkat $4 \%$. Sedangkan dalam aspek mengidentifikasi materi ajar berdasarkan silabus $71 \%$ guru dan kepala sekolah memenuhi kriteria, dan 29\% tidak memenuhi kriteria. Dalam hal ini juga bisa dikatakan meningkat, karena pada prasiklus para guru berkisar 53\% memenuhi kriteria, sedangkan pada siklus I ini $71 \%$ guru dan kepala sekolah yang memenuhi kriteria, artinya para guru dapat mengidentifikasi materi bahan ajar sesuai dengan silabus. Pada aspek menentukan metode pembelajaran $68 \%$ guru dan kepala sekolah memenuhi kriteria, dan $32 \%$ tidak memenuhi kriteria. Dalam aspek ini juga ada sedikit peningkatan, karena pada prasiklus hanya berkisar 39\% guru dan kepala sekolah memenuhi kriteria. Sedangkan pada siklus I hanya berkisar $68 \%$ guru memenuhi kriteria, artinya guru juga bisa meningkatkan dalam menentukan metode pembelajaran yang sesuai dengan kreativitas dan karakter masing-masing anak. Dalam aspek merumuskan langkah-langkah pembelajaran dari kegiatan awal, inti, dan akhir berkisar 80\% guru dan kepala sekolah memenuhi kriteria, dan $20 \%$ tidak memenuhi kriteria. Pada aspek ini juga ada peningkatan, karena pada prasiklus guru hanya berkisar $45 \%$ yang memenuhi kriteria, sedangkan pada siklus I berkisar $80 \%$ guru dan kepala sekolah memenuhi kriteria, artinya para guru bisa menyesuaikan antara kegiatan awal, kegaiatn inti, dan kegiatan akhir pembelajaran. Sedangkan pada aspek menentukan sumber belajar $80 \%$ guru dan kepala sekolah memenuhi kriteria, dan 20\% tidak memenuhi kriteria. Dalam aspek ini para guru dapat meningkatkan pemahaman dalam memilih alat dan bahan pembelajaran yang tepat sebagai sumber belajar.

Adapun dalam aspek menyusun kriteria penilaian 74\% guru dan kepala sekolah memenuhi kriteria, dan 26\% tidak memenuhi kriteria. Dalam aspek ini para guru pesat peningkatannya. Penilaian kurikulum 2013 memang agak rumit dan menyita waktu, namun para guru sangat antusias dalam mengikuti pelatihan. Dengan capain ini kinerja guru ada peningkatan yang sangat mengembirakan walaupun harus diadakan tindakan lanjutan.

\section{Siklus II}

Siklus II dilaksanakan pada tanggal 30 April 2021. Dalam pelaksanaan siklus II ditemukan bahwa kinerja guru pendidikan nonformal semakin meningkat, hal tersebut 
terlihat dari hasil yang diperoleh. Yaitu para guru dan kepala sekolah mampu mendapat nilai rata-rata 80 hingga 90 setiap individu. Sedangkan hasil dari persentase dalam aspek mengisi kolom identitas berkisar $100 \%$ guru dan kepala sekolah memenuhi kriteria. Dalam aspek ini, nilai yang dicapai oleh para guru sangat memuaskan. Jika pada siklus I berkisar 74\% guru dan kepala sekolah memenuhi kriteria sedangkan pada siklus II $100 \%$ memenuhi kriteria. Artinya para guru bisa meningkatkan kwalitas sebagai pendidik. Maka dalam aspek ini bisa dikatakan memenuhi ketentuan yang hendak dicapai. Adapun dalam aspek menentukan alokasi waktu sekitar 95\% guru dan kepala sekolah memenuhi kriteria, dan 5\% tidak memenuhi kriteria. Maka dalam aspek ini juga meningkatb pesat, karena pada siklus I para guru hanya sekitar $68 \%$ guru dan kepala sekolah memenuhi kriteria, sedangkan pada siklus II ini berkisar 95\% guru dan kepala sekolah memenuhi kriteria. Artimya, para guru dapat meningkatkan kompetensinya sebagai pendidik. Adapun dalam aspek menentukan SK, KD, dan indikator $92 \%$ guru dan kepala sekolah memenuhi kriteria, dan $8 \%$ tidak memenuhi kriteria. Pada aspek ini para guru benar-benar fokus dalam pelaksanaan pelatihan. Karena para guru ingin benar-benar menentukan standar kompetensi yang sesuai dengan kompetensi dasar dan indikator sesuai arahan dari peneliti dan nara sumber yang llain. Hal tersebut terlihat dari hasil pelaksanaan siklus II ini. Karena memang pada waktu penjelasan materi para guru tidak ada yang keluar masuk kelas, semaunya diam menyimak apa yang dijelaskan oleh pemateri, baik dari peneliti maupun dari nara sumber yang lain.Pada aspek merumuskan tujuan pembelajaran berdasarkan standar kompetensi, kompetensi dasar, dan indikator berkisar $95 \%$ guru dan kepala sekolah memenuhi kriteria, dan 5\% tidak memenuhi kriteria. Pada penilaian aspek ini juga sangat signifikan peningkatannya. Karena pada prasiklus I para guru hanya berkisar 77\% guru dan kepala sekolah memenuhi kriteria. Namun pada siklus II ini berkisar $95 \%$ guru dan kepala sekolah memenuhi kriteria. Maka hal tersebut bisa dikatakan berhasil dalam mengikuti pelaksanaan pelatihan RPPH. Adapun dalam aspek mengidentifikasi materi ajar berdasarkan silabus $89 \%$ guru dan kepala sekolah memenuhi kriteria, dan $11 \%$ tidak memenuhi kriteria. Maka dalam aspek ini juga bisa dikatakan berhasil, karena pada siklus I hanya $71 \%$ guru dan kepala sekolah memenuhi kriteria. Hal tersebut disebabkan oleh kesungguhan guru dalam mengikuti pelatihan. Sedangkan pada aspek menentukan metode pembelajaran 92\% guru dan kepala sekolah memenuhi kriteria, dan 8\% tidak memenuhi kriteria. Maka dalam hal ini sangat signifikan peningkatannya, karena pada siklus I hanya $68 \%$ guru dan kepala sekolah memenuhi kriteria, dan pada siklus II 92\% memenuhi kriteria. Ini menunjukkan bahwa para guru sangat fokus dalam mengikuti pelatihan. Adapun dalam aspek merumuskan langkahlangkah pembelajaran dari kegiatan awal, inti, dan akhir 100\% guru dan kepala sekolah memenuhi kriteria, dan 0\% tidak memenuhi kriteria. Pada aspek ini juga sangat pesat peningkatannya, karena pada siklus I berkisar $80 \%$ guru dan kepala sekolah memenuhi kriteria, sedangkan pada siklus II hingga $100 \%$ memenuhi kriteria. Artinya para guru telah bisa menyesuaikan antara program kegiatan awal, program kegaiatn inti, dan program kegiatan akhir pembelajaran. Hal tersebut menunjukkan bahwa para guru semakin menguasai program kegiatan pembelajaran. Dalam aspek menentukan sumber belajar 98\% guru dan kepala sekolah memenuhi kriteria, dan 2\% tidak memenuhi kriteria. Dalam aspek ini para guru dapat meningkatkan pemahaman dalam memilih alat dan bahan pembelajaran yang tepat sebagai sumber belajar. Hal tersebut terlihat dari 
peningkatan hasil penilaian dari pra siklus, siklus I, dan siklus II yang mencapai hingga 98\% memenuhi kriteia.

Sedangkan pada aspek menyusun kriteria penilaian 100\% guru dan kepala sekolah memenuhi kriteria, dan 0\% tidak memenuhi kriteria. Dalam aspek ini para guru sangat pesat peningkatannya. Namun para guru sangat antusias dalam mengikuti pelaksanaan pelatihan, karena memang hasil penilaiannya akan digunakan pada semester II tahun ajaran 2020/2021 yang akan berakhir, rentang dua bulan lagi para guru akan menilai peserta didik PAUD dan TK yang berada di sekolah masing-masing. Oleh karena itu, guru sangat fokus dalam mengikuti materi penilaian, terutama penilaian kurikulum 2013. Maka berdasarkan hasil tersebut kriteria telah memenuhi target yang hendak dicapai. Oleh karena itu tindakan sekolah dihentikan.

\section{KESIMPULAN}

Berdasarkan hasil penelitian, dapat disimpulkan bahwa kinerja guru PAUD dan TK di lingkungan Korwil Bidang Pendidikan Kecamatan Kokop Kabupaten Bangkalan harus ditingkatkan. Maka untuk meningkatkan guru harus dilakukan pendampingan dan bimbingan, baik berupa supervisi maupun pelatihan. Hal tersebut dapat dibuktikan dari hasil pelatihan yang dilaksanakan. Oleh karena itu pelatihan membuat Rencana Pelaksanaan Pembelajaran Harian (RPPH) dapat meningkatkan kinerja guru dan kepala sekolah PAUD dan TK dilingkungan Korwil Bidang Pendidikan Kecamatan Kokop.

Telah terbukti bahwa pelatihan dapat meningkatkan kinerja guru PAUD dan TK di lingkungan Korwil Bidang Pendidikan Kecamatan Kokop. Maka peneliti menyarankan bahwa kinerja dan motivasi harus ditanamkan dalam pribadi masingmasing guru, oleh karena itu guru harus mendapat bimbingan dari pemangku pendidikan.

Pelatihan juga harus selalu digalakkan, karena melalui pelatihan dapat meningkatkan motivasi dan kinerja guru di lingkungan Korwil Bidang Pendidikan Kecamatan Kokop.

\section{DAFTAR PUSTAKA}

Arifin, Zainal. "PENINGKATAN KEMAMPUAN GURU DALAM MEMBUAT RENCANA PELAKSANAAN PEMBELAJARAN (RPP) TEMATIK 1 HALAMAN MELALUI WORKSHOP DARING DENGAN VARIASI MODEL JIGSAW DI UNIT PELAKSANA TEKNIS DAERAH (UPTD) SEKOLAH DASAR (SD) NEGERI GENTENG 2 BANGKALAN." Re-JIEM (Research Journal of Islamic Education Management) 3, no. 2 (2020): 201-15. https://doi.org/10.19105/re-jiem.v3i2.4722.

Bachri, Bachtiar S. "Meyakinkan Validitas Data Melalui Triangulasi Pada Penelitian Kualitatif." Teknologi Pendidikan 10 (2010): 46-62.

Black, Nick. Consensus Development Methods: A Review of Best Practice in Creating Clinical Guidelines. Oxford: Blackwell Publishing, 2006.

Fadillah, Muhammad. Desain Pembelajaran PAUD. Yogyakarta: Ar Ruzz Media, 2012. Gunawan, Imam. Metode Penelitian Kualitatif Teori \& Praktek. Jakarta: PT. Bumi Aksara, 2014.

Mulyadi, Mohammad. "Penelitian Kuantitatif Dan Kualitatif Serta Pemikiran Dasar Menggabungkannya.” Jurnal Studi Komunikasi Dan Media 15, no. 1 (2013): 128. 
https://doi.org/10.31445/jskm.2011.150106.

Mursid. Pengembangan Pembelajaran PAUD. Bandung: Remaja Rosdakarya, 2016.

Nainggolan. Peningkatan Kinerja Penilik PNFI Untuk Pemberdayaan Program PNFI Di Asahan. Jakarta: Depdiknas, 2006.

Narbuko, C., and Ahmadi A.H. Metodologi Penelitian. Jakarta: Bumi Aksara, 2004.

Nawawi, Hadari. Metode Penelitian Bidang Sosial. Yogyakarta: Gadjah Mada University Press, 1985.

Sulistiatik, Atik. "UPAYA PENINGKATAN KEMAMPUAN GURU SMA DALAM MELAKSANAKAN PEMBELAJARAN MELALUI SUPERVISI AKADEMIK DI SEKOLAH BINAAN KABUPATEN BANGKALAN." Re-JIEM (Research Journal of Islamic Education Management) 2, no. 1 (2019): 119-30. https://doi.org/https://doi.org/10.19105/re-jiem.v2i1.2455.

Suyadi. Manajemen PAUD TPA-KB-TK/RA. Yogyakarta: Pustaka Pelajar, 2011.

Wiyani, Novan Andri, and Barnawi. Format PAUD. Yogyakarta: Ar Ruzz Media, 2012. Yusuf, Mohammad. "PENINGKATAN KEMAMPUAN GURU DALAM MENENTUKAN KRITERIA KETUNTASAN MINIMAL (KKM) MELALUI WORKSHOP DI UPTD SDN BANDA SOLEH 1 KECAMATAN KOKOP KABUPATEN BANGKALAN TAHUN 2019." Re-JIEM (Research Journal of Islamic Education Management) 2, no. 1 (2019). https://doi.org/https://doi.org/10.19105/re-jiem.v2i1.2456. 